Bulletin of the Natural History Museum, 2020, 13: 203-210.

Received 15 Oct 2020; Accepted 27 Oct 2020.

doi: $10.5937 / \mathrm{bnhmb} 2013203 \mathrm{~T}$

UDC: $582.663 .2(497.11)$

Short communication

\title{
AMARANTHUS TUBERCULATUS (MOQ.) J. D. SAUER: A NEW NATURALIZED ALIEN SPECIES IN SERBIA
}

\author{
MiLENA TABAŠEVIĆ*, SNEŽANA VUKOJIČIĆ, SLOBODAN JOVANOVIĆ \\ University of Belgrade, Faculty of Biology, Institute of Botany and Botanical \\ Garden "Jevremovac”, Serbia, e-mail: milenatabasevic@gmail.com
}

Genus Amaranthus L. is so far represented by following introduced taxa in the flora of Serbia: A. albus L., A. blitoides S. Watson, A. blitum L., A. caudatus L., A. crispus (Lesp. \& Thévenau) J. M. Coult. \& S. Watson, $A$. cruentus L., A. deflexus L., A. graecizans L., A. hybridus L., A. hypochondriacus L., A. retroflexus L. and A. viridis L. (Bokić et al. 2012, Iamonico 2015a). The data on the presence of $A$. powellii S. Watson in Serbia (Maly 1928) has not been confirmed recently. The majority of them are native to America, with the exception of $A$. blitum which originates from Mediterranean area and other parts of Europe and Northern Africa and $A$. graecizans native to parts of Europe, Central-Western Asia and Northern Africa (Iamonico 2015b). These monoecious amaranths are annuals (therophytes), except for $A$. deflexus which is a perennial (hemicryptophyte) (Bokić et al. 2012, Iamonico 2015b). In general, most amaranth species in Serbia are typical and common for ruderal and segetal habitats (Slavnić 1972, Bokić et al. 2012). Some representatives, such as A. caudatus, A. cruentus and A. hypochondriacus are grown as ornamentals (Slavnić 1972) and often may escape cultivation. In regard to the invasive status of these aliens, only $A$. retroflexus is listed as potentially invasive for the entire 
territory of Serbia (Lazarević et al. 2012), with the additional recommendation to include $A$. hybridus in the same category (Stojanović \& Jovanović 2018). In the Province of Vojvodina, even seven of the above-mentioned amaranth species are listed as invasive (Boža 2013, Stojanović \& Jovanović 2018). In this paper, we present a new alien species of the genus Amaranthus for the Serbian flora, i.e. the first records of Amaranthus tuberculatus (Moq.) J. D. Sauer in Serbia.

During extensive investigations of ruderal vegetation in cities across Serbia, based on collected plant specimens and digital photographs, the presence of $A$. tuberculatus was determined in sampled phytocenological relevés on the banks of the Sava River in cities of Šabac (in 2016) and Sremska Mitrovica (in 2018). With fieldwork conducted in two cities in 2020 , the species was reconfirmed in Šabac but also registered further downstream the Sava river, in the city of Belgrade. Thus, during the period of 4 years, the species was registered in Serbia in three cities of Srem, Šumadija and North-western Serbia (Fig. 1).

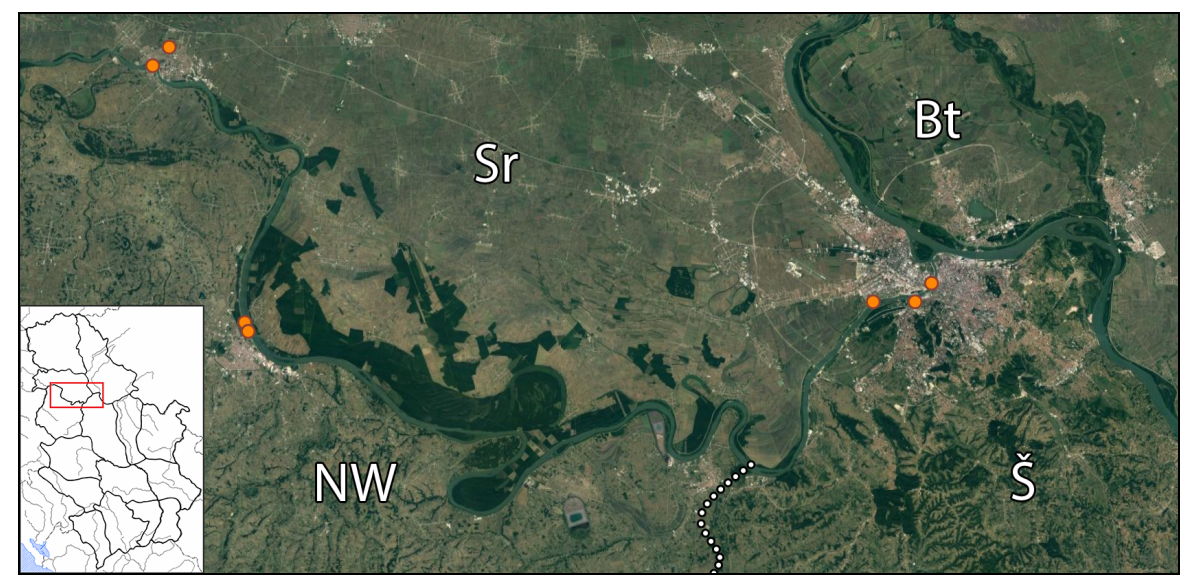

Fig. 1. - Registered localities of A. tuberculatus in Serbia (acronyms for geographical regions according to Stevanović 1992: $\mathrm{Sr}-\mathrm{Srem}, \mathrm{Bt}-$ Banat, NW - North-western Serbia, Š - Šumadija).

Voucher specimens were deposited in the Herbarium of the Institute of Botany and Botanical Garden "Jevremovac", Faculty of Biology, University of Belgrade (BEOU, acronym according to Thiers 2020). The identification of the material was done following Costea et al. (2005) and Iamonico (2015b). The nomenclature of Amaranthus species is in accordance with EURO+MED Plantbase (Iamonico 2015a). The distribution map was prepared in the software Google Earth Pro.

Amaranthus tuberculatus, known as rough-fruited water-hemp or common water-hemp, is an annual (therophyte) plant, originating from 
North America. Plants can grow tall up to $200(-300) \mathrm{cm}$. Stems are glabrous, branched and often reddish. Leaves alternate, petioled, glabrous, ovate to lanceolate. Inflorescence terminal, spike- or panicle-like, often reddish. Dioecious species, male and female flowers occur on separate plants. Flowers bracts 1, with an acuminate apex. Male flowers have 5 ovate to lanceolate tepals. Female flowers without or with 1 narrowlanceolate tepal, rarely 2 tepals, style lacking, stigmas 3, prominent, long and feathery. Fruit is a single-seeded ovate, rugose utricle. For more details see Pratt \& Clark (2001), Costea et al. (2005), Iamonico (2015b, 2015c). According to Costea \& Tardif 2003, within the species, two varietal taxa are recognized based on differences in the number of the tepals on female flowers and dehiscence/indehiscence of the fruit, ie. A. tuberculatus var. tuberculatus and A. tuberculatus var. rudis. On the other hand, in an earlier study by Pratt \& Clark (2001), these descriptions were considered as extremes of one polymorphic species, hence the names of two traditionally divided water-hemps, A. rudis J. D. Sauer and A. tuberculatus (Moq.) J. D. Sauer were synonymized. In this paper we focused only on the species level.

A. tuberculatus is so far the only dioecious amaranth species in Serbia. The presence of unisexual flowers only, makes it relatively easy to notice and identify. Furthermore, it can be distinguished from A. retroflexus and $A$. hybridus by the usually narrower leaves during the vegetative stage (Costea et al. 2005). Rough-fruited water-hemp usually occurs on margins of freshwaters, after the water level drops, but also along roadsides, railroads, and in agricultural fields (Pratt \& Clark 2001, Costea et al. 2005, Iamonico 2015c).

\section{Chorological data:}

SREM, Sremska Mitrovica: Radinački Put, 445' $56.7^{\prime \prime}$ N, 19³6' 37.6" E, $81 \mathrm{~m}$, only a few individuals along the edge of the road (Tabašević, $M$. field obs., 29.09.2018); Sava river, 4458'25.0" N, 19³5'37.7" E, $78 \mathrm{~m}$, along the riverbank, few dozen individuals in 5 sampled relevés along the $600 \mathrm{~m}$ long segment downstream (Tabašević, M. field obs., 30.09.2018); Belgrade: New Belgrade, Block 45 - Block 70, Sava river, 44047' 33.1" N, $20^{\circ} 22^{\prime} 46.9^{\prime \prime} \mathrm{E}, 72 \mathrm{~m}$, along the riverbank, $2 \mathrm{~km}$ long segment with discontinuous populations of few dozen individuals, plants growing in crevices of the concrete embankments (Vukojičić, S. 17706, BEOU 4.10.2020); New Belgrade - Staro Sajmište, Sava river, 44²48'24.60" N, $20^{\circ} 26 ' 37.20^{\prime \prime} \mathrm{E}, 70 \mathrm{~m}$, along the riverbank, $800 \mathrm{~m}$ long segment downstream with scattered plants growing on the concrete embankments, including two small stands $\left(10-20 \mathrm{~m}^{2}\right)$ on the ground surface at the bottom of the embankment with a large number of individuals (Tabašević, $M$. 17707, BEOU, 27.09.2020). 
ŠUMADIJA, Belgrade, Savski Venac, Sava river near Ada Bridge, $44^{\circ} 47^{\prime} 30.60$ "N, 20²5'29.50" E, $71 \mathrm{~m}$, along the riverbank, $350 \mathrm{~m}$ long segment downstream with scattered plants growing in crevices of the concrete embankments, reaching higher numbers in several locations at the bottom of the embankment (Tabašević, M. BEOU 17705, 30.09.2020).

NORTH-WESTERN SERBIA, Šabac: Sava river, 444ㅇ'07.1" N, $19^{\circ}$ 41'59.6" E, $79 \mathrm{~m}$, along the riverbank, $300 \mathrm{~m}$ long segment downstream with few dozen individuals (Tabašević, M. BEOU 17703, 26.09.2016); Sava river, 444' $33.7^{\prime \prime} \mathrm{N}, 19^{\circ} 41^{\prime} 45.9^{\prime \prime} \mathrm{E}, 74 \mathrm{~m}$, along the riverbank, discontinuous stands along $1 \mathrm{~km}$ long segment downstream, in some particular stands up to hundreds of individuals with high cover values (Tabašević, M. BEOU 17704, 25.09.2020).

In Serbia, A. tuberculatus was primarily observed in disturbed riparian habitats. It was registered within the communities of the vegetation class Bidentetea Tx. et al. ex von Rochow 1951, summer-annual pioneer vegetation of seasonally flooded nutrient-rich river alluvia (Figs 2-3). In Sremska Mitrovica the species was also registered in higher numbers within the stands with domination of Amorpha fruticosa L. All localities are situated along the Sava riverbank, with the exception of one locality in Sremska Mitrovica, situated $1.5 \mathrm{~km}$ away from the river. During field investigations in 2020, on each site fully developed male and female individuals were registered.

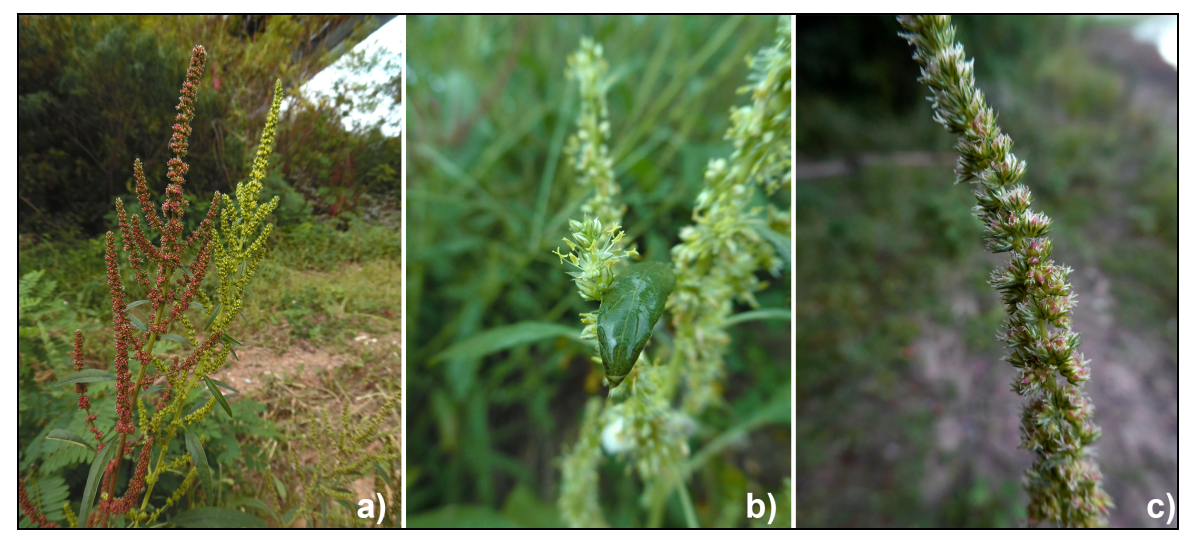

Fig. 2. - A.tuberculatus: a) female plant; b) details of a male flowers; c) details of a female flowers.

Amaranthus tuberculatus is introduced in several European countries, but only in Italy it is considered as an invasive species, causing threat to native riparian herbaceous vegetation (Iamonico 2015c). Although the species has been present in the Balkans for some time now (Anastasiu \& Negrean 2006), recently it was registered for the first time in two 
neighbouring countries. Individual plants have been reported for the first time in Bosnia and Herzegovina (Maslo et al. 2020), while in Croatia, stable populations of $A$. tuberculatus were recorded along the banks and in the close vicinity of the Sava river (Rimac et al. 2020).

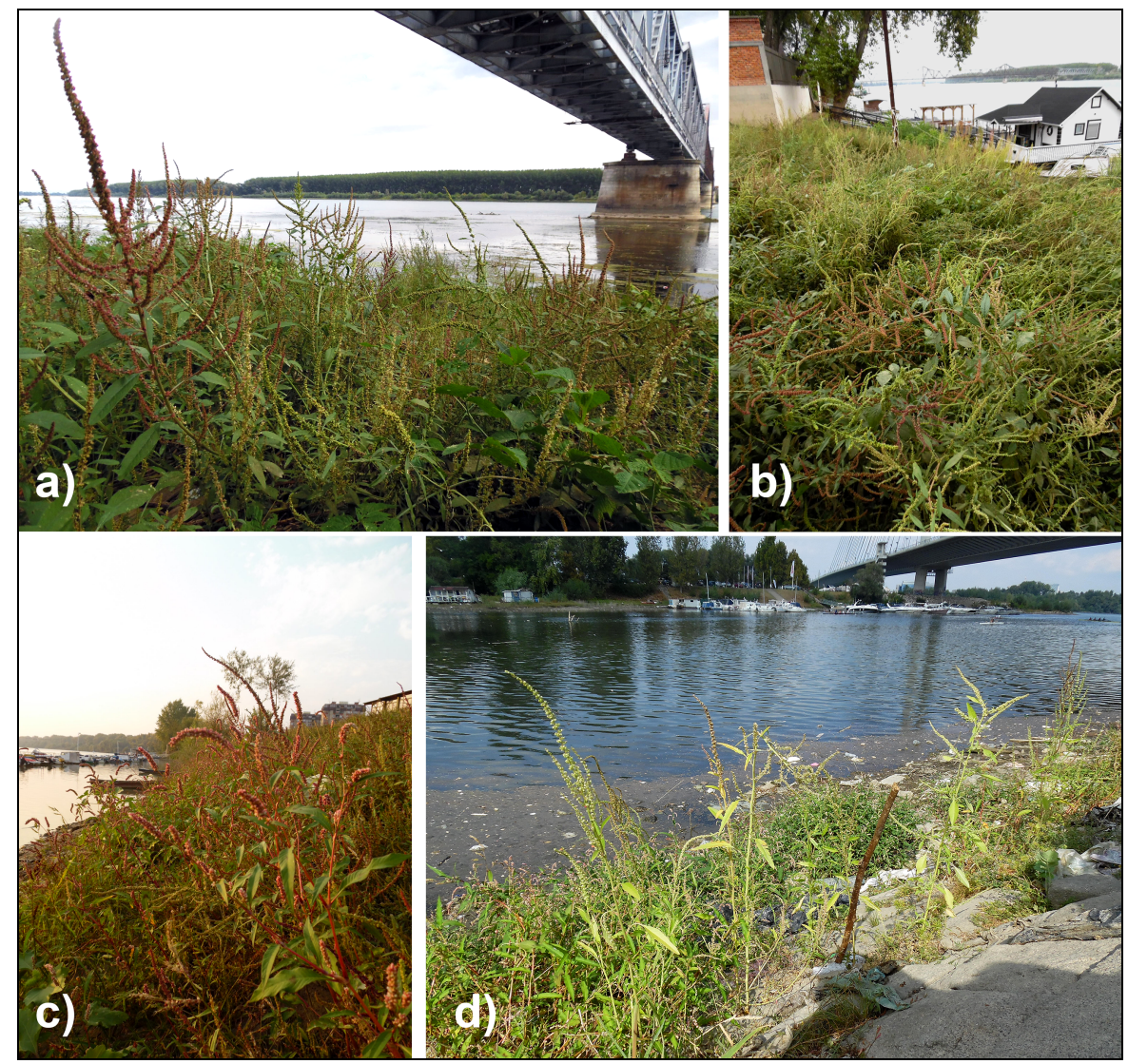

Fig. 3. - Habitats of A. tuberculatus on the Sava riverbank from Šabac (a, b), Sremska Mitrovica (c) and Belgrade (d).

Despite the fact that rough-fruited water-hemp is distributed along 130 $\mathrm{km}$ of the Sava river in Serbia, from Sremska Mitrovica to Belgrade, areas with confirmed presence of $A$. tuberculatus represent a small part of this great distance, an overall a bit more than $5 \mathrm{~km}$. Following the framework proposed by Blackburn et al. 2011, we can consider A. tuberculatus as naturalized, already in the D2 category (self-sustaining population in the wild, with individuals surviving and reproducing a significant distance from the original point of introduction). The same status of this alien was reported in Croatia as well (Rimac et al. 2020). According to the aforementioned framework, to consider a species fully invasive, the species should be present in a spectrum of habitats. 
Further continuous monitoring is required in order to prevent its possible spreading in the native vegetation. Additionally, the special concern should be on the potential spread and effect of this alien on the autochthonous flora and fauna in the nearby protected areas located along the Sava River basin in Serbia, special nature reserves Zasavica and Obedska bara. These nature reserves are recognized as areas of international importance included in the list of Ramsar sites, Important Bird Areas (IBA), Important Plant Areas (IPA), EMERALD Areas, Sava river Basin Protected Areas Network - SavaParks, as well as the potential NATURA 2000 areas (Puzović et al. 2015).

\section{Acknowledgements}

This work was supported by the Ministry of Education, Science and Technological Development of the Republic of Serbia (Grant number 45103-68/2020-14/200178). We are grateful to Miša Jovanović for assistance during the fieldwork.

\section{REFERENCES}

Anastasiu, P., Negrean, G. (2006): Alien vascular plants in Dobrogea (Romania) and their impact on different types of habitats . In: Ivanova, D. (ed.): Plant, fungal and habitat diversity investigation and conservation. Proceedings of IV Balkan Botanical Congress, Sofia, 20-26 June 2006: 590-596. - Institute of Botany, Sofia.

Blackburn, T. M., Pyšek, P., Bacher, S., Carlton, J. T., Duncan, R. P., Jarošík, V., Wilson, J. R., Richardson, D. M. (2011): A proposed unified framework for biological invasions. - Trends in Ecology and Evolution 26(7): 333-339.

Bokić, B., Knežević, J., Ječmenica, V., Bratić, N., Anačkov, G. (2012): Biology, life strategy and invasiveness of species of the genus Amaranthus L. in Pannonian part of Serbia. In: Proceedings of the International Symposium on Current Trends in Plant Protection: 127-136. - Institute for Plant Protection and Environment, Belgrade.

Boža, P. (2013): Amaranthus L. In: Anačkov, G., Bjelić-Čabrilo, O., Karaman, I., Karaman, M., Radenković, S., Radulović, S., Vukov, D. Boža, P. (ed.): Lista invazivnih vrsta na području AP Vojvodine. - Departman za biologiju i ekologiju, Prirodno-matematički fakultet, Univerzitet u Novom Sadu. [http://iasv. dbe.pmf.uns.ac.rs/index.php ver 0.2 beta] [accessed $20^{\text {th }}$ January 2021]

Costea, M., Tardif, F. J. (2003): Conspectus and notes on the genus Amaranthus in Canada . - Rhodora 105: 260-281.

Costea, M., Weaver, S. E., Tardif, F. J. (2005): The Biology of Invasive Alien Plants in Canada. 3. Amaranthus tuberculatus (Moq.) Sauer var. rudis (Sauer) Costea \& Tardif. - Canadian Journal of Plant Science 85(2): 507-522. 
Iamonico, D. (2015a): Amaranthaceae. In: Euro+Med PlantBase - the information resource for Euro-Mediterranean plant diversity. [http://ww2.bgbm.org/Euro PlusMed/query.asp] [accessed $17^{\text {th }}$ September 2020]

Iamonico, D. (2015b): Taxonomic revision of the genus Amaranthus (Amaranthaceae) in Italy. - Phytotaxa 199(1): 1-84.

Iamonico, D. (2015c): Amaranthus tuberculatus (rough-fruited water-hemp). In: Invasive Species Compendium (CABI). - CAB International, Wallingford, UK. [https://www.cabi.org/isc] [accessed $17^{\text {th }}$ September 2020]

Lazarević, P., Stojanović, V., Jelić, I., Perić, R., Krsteski, B., Ajtić, R., Sekulić, N., Branković, S., Sekulić, G., Bjedov, V. (2012): Preliminarni spisak invazivnih vrsta u Republici Srbiji sa opštim merama kontrole i suzbijanja kao potpora budućim zakonskim aktima. - Zaštita prirode 62(1): 5-32. [in Serbian with English Abstract]

Maly, K. (1928): Prilozi za floru Bosne i Hercegovine. - Glasnik Zemaljskog muzeja u Bosni i Hercegovini 40: 107-166. [in Serbo-Croatian]

Maslo, S., Šarić, Š., Sarajlić, N. (2020): Rough-fruit amaranth Amaranthus tuberculatus (Amaranthaceae): a new alien species in the flora of Bosnia and Herzegovina and the Balkans. - Phytologia Balcanica 26(1): 25-28.

Puzović, S., Panjković, B., Tucakov, M., Stojnić, N., Sabadoš, K., Stojanović, T., Vig, L., Marić, B., Tešić, O., Kiš, A., Galamboš, L., Pil, N., Kicošev, V., Stojšić, V., Timotić, D., Perić, R., Bošnjak, T., Delić, J., Dobretić, V., Stanišić, J. (2015): Upravljanje prirodnom baštinom u Vojvodini. - Pokrajinski sekretarijat za urbanizam, graditeljstvo i zaštitu životne sredine i Pokrajinski zavod za zaštitu prirode, Novi Sad. [in Serbian]

Pratt, D. B., Clark, L. G. (2001): Amaranthus rudis and A. tuberculatus - one species or two?. - Journal of the Torrey Botanical Society 128(3): 282-296.

Rimac, A., Doboš, M., Šegota, V. (2020): Amaranthus tuberculatus (Moq.) J.D. Sauer - a new alien pigweed species in Croatia. - BioInvasions Records 9(3): 642-654.

Slavnić, Ž. (1972): Rod Amaranthus L. In: Josifović, M. (ed.): Flora SR Srbije 3: 1-10. - Srpska akademija nauka i umetnosti, Beograd. [in Serbian]

Stevanović, V. (1992): Floristička podela teritorije Srbije sa pregledom viših horiona i odgovarajućih flornih elemenata. In: Sarić, M. R. (ed.): Flora Srbije 1: 49-53. - Srpska akademija nauka i umetnosti, Beograd. [in Serbian]

Stojanović, V., Jovanović, I. (2018): The survey of invasive and potentially invasive plant species in Serbia and neighbouring countries for the purpose of determining their status at the national level. - Zaštita prirode 68(1-2): 41-59.

Thiers, B. (2020+): Index Herbariorum: A global directory of public herbaria and associated staff. - New York Botanical Garden's Virtual Herbarium. [http://weetgum. nybg.org/ih/] [accessed $25^{\text {th }}$ November 2020] 


\section{Amaranthus tuberculatus (MOQ.) J. D. SAUER: Hoba НАТУРАЛИЗОВАНА СТРАНА ВРСТА У СРБИЈИ}

МИЛЕНА ТАБАШЕВИЋ, СНЕЖАНА ВУКОЈИЧИЋ, СЛОБОДАН ЈОВАНОВИЋ

$$
\text { Р Е } 3 \text { И М Е }
$$

Током истраживања рудералне вегетације у градовима широм Србије, у три града у долини реке Саве забележена је нова страна врста за флору Србије, Amaranthus tuberculatus (Amaranthaceae). A. tuberculatus је једногодишња биљка пореклом из Северне Америке и за сада једина дводома врста рода Amaranthus у Србији. Натурализоване популације су примарно забележене у ремећеним стаништима на обали реке Саве у Сремској Митровици, Шапцу и Београду. Врста $A$. tuberculatus је недавно по први пут регистрована у две суседне земље, што додатно указује на ширење ареала врсте на Балкану. 